\title{
CORRESPONDENCE
}

\section{Stages of the Llandovery Series}

SIR,-It may well be that the names of the stages of the Llandovery Series should be formalized, and the proposals put forward by Messrs. Cocks, Toghill, \& Ziegler (Geol. Mag. 107, 1970, pp. 79 ff) are in principle very welcome. But the proposals themselves invite criticism.

The proposals are scarcely of Standard Stages: if they are, they should remain provisional until (after discussion) they are approved by I.U.G.S. (through its Commission on Stratigraphy, the Subcommission on Stratigraphical Nomenclature, and the Stratigraphy Committee of the Geological Society of London). On the other hand, the stages are perhaps named merely as local stages, 'a substitute or alternative for the letters and numbers ... . used by Jones', and then are more immediately acceptable. In either case, strong objection must be taken to the location of the base of the series.

It is perverse to designate stages to replace Jones's groups, and then to define the base of the lowest stage at a horizon (technically an insubstantial bedding-plane, for the rocks above are stratotyped elsewhere) in a graptolitic facies that is not commensurate with the shelly facies of Jones's sequence. It is doubly perverse to do so in a province far removed from the stratotype, when a completely satisfactory base can be equally precisely located at the selected horizon only four or five miles $(6-8 \mathrm{~km})$ across the Towy anticline from Llandovery. The authors discount work on the graptolite sequence in mid-Wales; but the repeated use by Jones himself, by Pugh, and notably by Davies (who described in detail the sequence near Llandovery), of the base of the persculptus Zone as the base of the series, leaves no ambiguity about established practice, even if the concept of stratotype had not emerged when the work was done. If the base of the Llandovery Series is to be at a graptolite horizon-an unhappy proposal-it would be much more appropriately located in the Pumpsaint-Abergwesyn ground than at Dobb's Linn 230 miles $(400 \mathrm{~km})$ away.

When Welsh place-names are used as stage names, Welsh orthography should be respected. 'Idwian' is gratuitously mis-spelled: the river from which the name is taken is called 'Ydw' (root 'yd-', 'corn'-'Afon Ydw', 'the river that winds through the cornfields' - there is in Welsh no root 'id-'), and the stage name should be 'Ydwian'.

'Fron' is abbreviated from ' $Y$ Fron' ('the breast' of a hill, 'the mount'). The 'F-' is mutant from ' $B$-' after the ' $Y$ ', the root word being 'bron'. The stage should be 'Bronian' (a poor choice in any case, for there are dozens of brons and frons as place-names in Wales).

T. Neville George

Department of Geology

University of Glasgow

Glasgow, W.2.

18th January 1971

\section{Stages of the Llandovery Series-A Reply}

SIR, - We are glad that Professor George agrees with us in taking the base of the persculptus Zone as the base of the Llandovery Series. Although he speaks of the acceptance of this horizon as 'established practice', this was by no means so in the first forty years of this century, and we welcome Professor George's endorsement of this level for the boundary. One important fact needs re-emphasis; namely that the base of the Llandovery Series in the shelly facies at Llandovery cannot be precisely correlated with horizons elsewhere. Thus, if the term 'Llandovery', and, indeed, even 'Silurian' is to be used unambiguously by stratigraphers in Britain and overseas, its base must be defined away from the Llandovery area. We do not consider ourselves perverse in defining the 
base of the series in a facies not commensurate with the shelly facies at Llandovery. Indeed, we feel there is no alternative, short of abandoning the Llandovery area completely and defining all the stages in the graptolitic facies. We suspect that Professor George agrees with us since he suggests no alternative shelly facies area for the boundary. We feel that we have made the best compromise in retaining the Llandovery area as the type area for the Series, but defining its base in the graptolitic facies.

We are surprised by Professor George's advocacy of the Pumpsaint-Abergwesyn ground as a suggested place for the definition of the type horizon. Despite its geographical proximity to Llandovery, the two areas are entirely dissimilar, since both facies and fauna change across the Towy anticline, thus any correlation between the two is entirely palaeontological. Davies' (1933) masterly study of this difficult Abergwesyn area revealed that, although the persculptus Zone is present, the Bala rocks are poorly fossiliferous, and that the Ashgill is represented only by a sparse shelly fauna. The highest accurately-dated Ordovician fauna is from the clingani Zone of the Caradoc. Davies is worth quoting in full on the boundary (1933, pp. 177-8):

'The tracing of the junction between the Bala and the Valentian series, which is easy in many parts of Central Wales (as, for example, at Machynlleth), is difficult in the Abergwesyn-Pumpsaint country. On the north-west, it is true, the blue-black shales of the Bala stage, with their subdued weathering tints and highly characteristic double cleavage, are followed by a few feet of easily differentiated dark shales, and these latter by the mottled mudstones of the Glyptograptus persculptus Zone. But in certain localities, such as that on the Towy south of Dolachddu, the cleaved nature of the shales at the top of the Bala series is lost, and blue mudstones very similar to those of the Lower Birkhill take their place. Around the Pumpsaint gold mines, too, it is difficult to determine precisely which rocks are Bala and which are Valentian; here, the difficulty is increased by the intense folding and faulting which the rocks have experienced.'

Hardly the description of an area ideal for the definition of a system boundary; we do not consider ourselves perverse in its rejection. The Abergwesyn-Pumpsaint area and the Llandovery area are no more similar to each other than Dobb's Linn and Llandovery (except in their mutual lack of useful fossils in the Bala).

Since the boundary had to be removed from Llandovery, the most suitable locality was sought. Dobb's Linn was chosen because it has all the zones of both Upper Ordovician and Lower Silurian continuously exposed and bountifully fossiliferous; the graptolite faunas across the boundary have recently been revised; there is no hint of unconformity; and the site is easily accessible. The fact that it was also the most classic locality of Lapworth himself made our choice even less equivocal. It was Lapworth who, in defining the Ordovician System in 1879, defined the base of the Silurian System at the base of the Llandovery Series, a level he emphatically equated elsewhere with the base of the Birkhill Shales, whose type locality is at Dobb's Linn. We consider this a better place for a formal boundary (whose correlation level seems to be in any case agreed) than anywhere in Wales.

Our proposals were for standard stages. They are no more 'provisional' than those of Bancroft for the Caradoc, Holland, Lawson and Walmsley for the Ludlow, or Ingham and Wright for the Ashgill. If geologists find our stages useful, they will stand, if not they will be discarded; no national or international rules are yet mandatory or even agreed in stratigraphy.

As for the names themselves, their choice was left to Dr D. A. Bassett of the National Museum of Wales, who very kindly suggested the sequence 'Rhuddanian, Ydwian, Fronian, Telychian'. The Ordnance Survey is followed in using the term Fron rather than Bron, the name is marked as such without prefix on all maps. We took the responsibility for the substitution of ' $\mathrm{I}$ ' for ' $\mathrm{Y}$ ' in the second stage name, because we felt that the correct Welsh spelling would be confusing to most geologists here and abroad. Revision of the names is not contemplated, and indeed to suggest their revision hardly contributes to the stability of geological literature, since they have already been used in several publications. 


\section{Reference}

Davies, K. A. 1933. The geology of the country between Abergwesyn (Breconshire) and Pumpsaint (Carmarthenshire). Q. Jl geol. Soc. Lond. 89, 172-201, pls 17, 18.

L. R. M. Cocks and P. Toghill

British Museum

Dept. of Palaeontology

London, S.W.7.

19th March 1971. 